\title{
INTRODUKSI TEKNOLOGI PEMBUATAN PUPUK ORGANIK PADA KELOMPOK TERNAK SUNGKAI PERMAI
}

\author{
Fitrimawati*)., Dwi Yuzaria dan Ismet Iskandar \\ Fakultas Peternakan Universitas Andalas \\ ${ }^{*}$ Email: fitrimawati@yahoo.com
}

\begin{abstract}
ABSTRAK
Kegiatan telah dilakukan di kampung Sungkai kelurahan Lambung Bukit Kecamatan Pauh Kota Padang. Sejak dahulu, peternak di kampung Sungkai telah memanfaatkan kotoran ternak untuk memupuk tanaman pertanian. Namun pemakaian kotoran ternak secara langsung tanpa diproses lebih dahulu dapat membahayakan tanaman, ternak, bahkan manusia. Tingginya kesadaran masyarakat sekarang ini akan penggunaan pupuk organik untuk mengatasi kerusakan tanah akibat penggunaan pupuk kimia merangsang permintaan akan pupuk organik semakin meningkat. Oleh itu, kami melakukan pendampingan kepada kelompok ternak Sungkai Permai untuk membuka usaha pupuk organik. Ini merupakan peluang usaha bagi peternak rakyat Kampung Sungkai untuk meningkatkan pendapatan rumah tangga mereka. Metode pendekatan yang ditawarkan adalah metode penyuluhan dan metode demontrasi pembuatan pupuk organik serta metode pendampingan dalam proses produksi, packing dan pemasaran. Hasil dari pelaksanaan program adalah masyarakat memperoleh pengetahuan dan keterampilan pembuatan pupuk organik dan manajemen teknis beternak sapi potong secara intensif. Peternak telah memulai menghasilkan produk pupuk organik yang siap untuk dipasarkan. Peternak memperoleh design merek dari produk pupuk organik mereka.
\end{abstract}

Kata Kunci: pendampingan, usaha, pupuk organik, dan kelompok ternak, Sungkai Permai

\section{Technology Introduction of Organic Fertilizer Making on The Sungkai Permai of Farmer Group}

\begin{abstract}
Activities have been carried out in Sungkai village, Lambung Bukit sub-district, Pauh District, Padang City. Since long ago, farmers in Sungkai village have used livestock manure to fertilize agricultural crops. However, direct use of manure without being processed can endanger plants, livestock, and even humans. The current high public awareness of the use of organic fertilizers to overcome soil damage due to the use of chemical fertilizers stimulates the demand for organic fertilizer to increase. Therefore, we provide assistance to the Sungkai Permai livestock group to open an organic fertilizer business. This is a business opportunity for the people of Kampung Sungkai to increase their household income. The approach methods offered are extension methods and demonstration methods for making organic fertilizers as well as methods of assistance in the production, packing and marketing processes. The results of the program implementation were that the community gained knowledge and skills in making organic fertilizers and technical management of raising beef cattle intensively. Farmers have started to produce organic fertilizer products that are ready to be marketed. Farmers obtain brand designs from their organic fertilizer products.
\end{abstract}

Keywords: mentoring, business, organic fertilizer, and livestock groups, beautiful sungkai

\section{PENDAHULUAN}

Di Indonesia peternakan sapi potong mayoritas diusahakan oleh peternak rakyat dengan skala usaha yang kecil dan manajemen pemeliharaan secara sederhana dan tradisional. Usaha peternakan rakyat adalah usaha sambilan disamping usaha pokoknya 
sebagai petani tanaman pangan. Tujuan pemeliharaan adalah untuk menambah pendapatan keluarga, memanfaatkan kotoran sebagai pupuk lahan pertaniannya, memanfaatkan limbah pertanian untuk pakan dan sebagai tabungan hidup yang sewaktu waktu dapat diuangkan. Memelihara sapi sangat menguntungkan, karena tidak hanya menghasilkan daging atau susu, tetapi juga menghasilkan pupuk kandang.

Sejak dahulu, peternak di Indonesia telah memanfaatkan kotoran ternak untuk memupuk tanaman pertanian. Namun pemakaian kotoran ternak secara langsung tanpa diproses lebih dahulu dapat membahayakan tanaman, ternak, bahkan manusia. Hal tersebut disebabkan selama berada di dalam tanah terjadi dekomposisi bahan organik dengan hasil asam-asam organik, senyawa fenol, NH3, CO2, dan panas (Steinfeld et al, 2006). Bahan-bahan tersebut merupakan racun bagi tanaman. Oleh karena itu, kotoran ternak yang akan digunakan sebagai pupuk sebaiknya diolah lebih dahulu agar bahan organik tersebut dapat diubah menjadi senyawa organik dan anorganik yang siap digunakan oleh tanaman (Triatmojo et al, 2013). Selain itu, kotoran ternak mengandung bibit penyakit yang dapat menular ke hewan dan manusia.

Salah satu upaya yang dilakukan yaitu dengan mengembangkan penggunaan pupuk organik. Pupuk organik disamping menyediakan hara tanaman juga dapat memperbaiki struktur tanah, memperkuat zat hara tanah, meningkatkan daya tahan dan daya serap air, memperbaiki drainase dan pori-pori dalam tanah. Pupuk organik dalam bentuk yang telah dikomposkan ataupun segar berperan penting dalam perbaikan sifat kimia, fisika dan biologi tanah. Secara umum kandungan nutrisi hara dalam pupuk organik tergolong rendah dan agak lambat tersedia, sehingga diperlukan dalam jumlah cukup banyak. Namun pupuk organik yang telah dikomposkan dapat menyediakan hara dalam waktu yang lebih cepat dibandingkan dalam bentuk segar, karena selama proses pengomposan telah terjadi proses dekomposisi yang dilakukan oleh beberapa macam mikroba, baik dalam kondisi aerob maupun anaerob. Sumber bahan kompos antara lain berasal dari limbah organik seperti sisa-sisa tanaman (jerami, batang dan dahan), sampah rumah tangga serta kotoran ternak (sapi, kambing, ayam).

Tingginya kesadaran masyarakat sekarang ini akan penggunaan pupuk organik untuk mengatasi kerusakan tanah akibat penggunaan pupuk kimia meransang permintaan akan pupuk organik semakin meningkat. Ini merupakan peluang usaha bagi peternak rakyat untuk meningkatkan pendapatan rumah tangga mereka. Berdasarkan peluang tersebut maka kelompok ternak Sungkai Permai yang berlokasi di Kampung Bukit Sungkai kelurahan Lambuang Bukik Kecamatan Pauh Kota Padang akan merintis usaha pupuk organik yang dibina oleh tenaga pengajar fakultas Peternakan Universitas Andalas. Kelompok ternak ini bersebelahan dengan kampus Universitas Andalas. Kampung Sungkai terletak sebelah Timur Kota Padang, di Kecamatan Pauh, Kelurahan Lambung Bukit, berjarak dari Kampus Universitas Andalas sekitar 3 KM.

Lokasi kelompok ternak Sungkai Permai mempunyai kawasan padang rumput yang luas. Itulah sebabnya sebagian besar masyarakatnya adalah peternak. Kami menjumpai hampir setiap rumah tangga adalah beternak sapi. Ini membuktikan bahwa motivasi dan keinginan masayarakat untuk beternak sapi sangat tinggi yang didukung oleh sumber hijauan yang banyak tersedia disana. Namun mereka mempunyai kendala dalam hal pengadaan bibit sapi. Ini terbukti dari mayoritas mereka memelihara sapi seduaan yaitu mereka memelihara sapi milik orang lain dan jika beranak maka anaknya dibagi dua. Sistem dan manajemen pemeliharaan sapi masih tradisional dan belum tersentuh oleh perkembangan IPTEKS. Populasi sapi per peternak adalah berkisar 1-5 ekor. Bibit sapi 
yang mereka gunakan adalah bibit sapi lokal. Pakan yang diberikan kepada ternak adalah rumput lapangan dan sebahagian peternak mempunyai sedikit rumput gajah. Sistem pemeliharaan yang mereka gunakan mayoritas adalah dengan sistem intensif namun masih tradisional. Sebagian besar peternak mempunyai padang rumput yang luas untuk pengembalaan sapi mereka. Bila dilihat dari kondisi kandang maka kandang ternak mereka tidak permanen dan masih berlantai tanah dan kotoran sapi ditumpuk disamping kandang.

Semua itu sebenarnya merupakan potensi yang besar untuk membangun usaha pupuk organik oleh kelompok ternak Sungkai Permai. Masing-masing peternak mengumpulkan kotoran ternaknya untuk usaha pupuk organik kelompoknya.

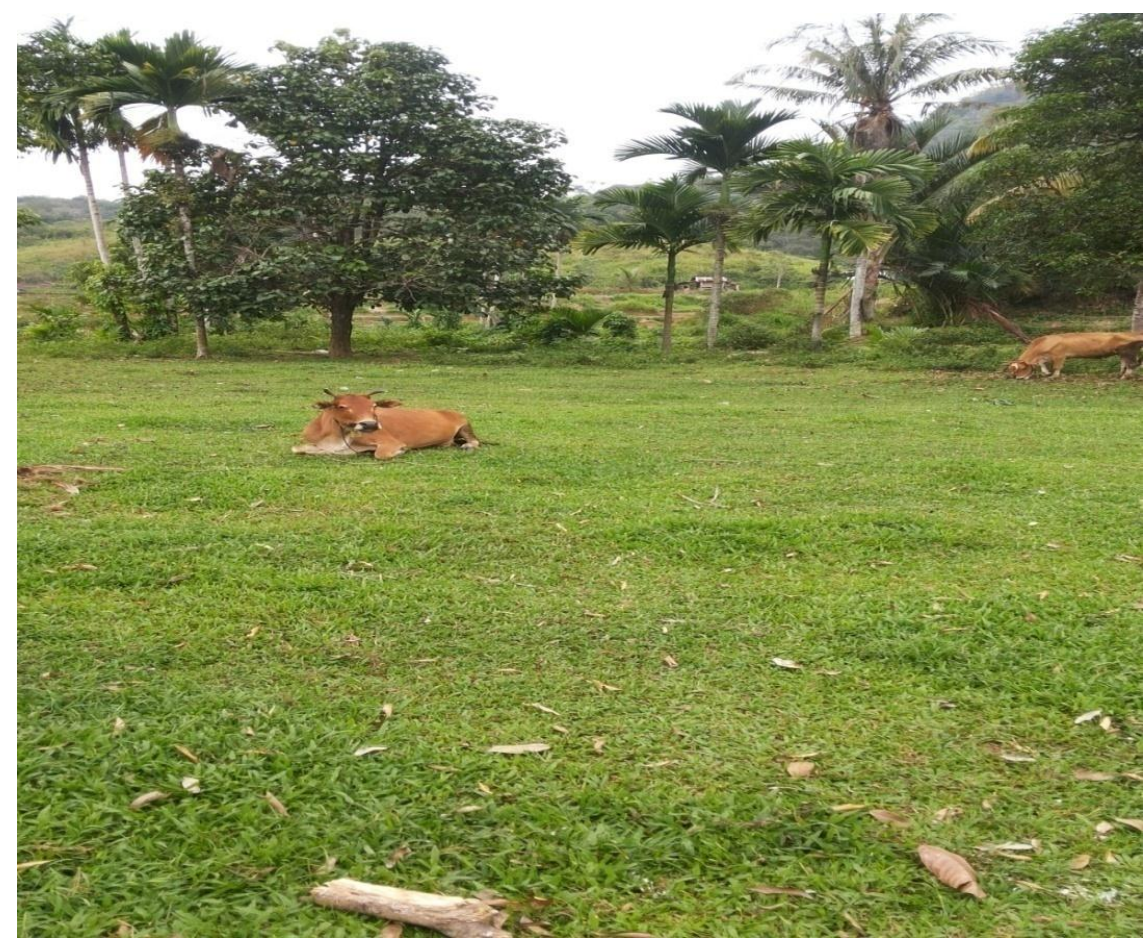

Gambar 1. Potensi Daerah Kelompok Ternak Sungkai Permai

\section{Permasalahan Mitra}

Kelompok Tani Ternak Sungkai Permai memiliki potensi besar di bidang peternakan sapi potong bila dilihat dari potensi lahan dan sumber pakan. Namun pendapatan peternak masih sangat rendah disebabkan usaha peternakannya masih skala usaha peternakan rakyat dan belum berorentasi profit. Hal itu terjadi karena kurangnya sumber modal untuk pembelian bibit, manajemen teknis beternak sapi masih kurang dan belum adanya manajemen agribisnis terutama manajemen keuangan masih minim serta kurangnya penggunaan teknologi. Penerimaan yang seharusnya dapat diperoleh dari hasil kotoran sapi tidak dimanfaatkan semaksimal mungkin untuk peningkatan pendapatan.

Dari semua persolan dan permasalahan yang dialami mitra baik dalam bidang produksi dan peningkatan populasi ternak, pemberian pakan, manajemen kandang dan 
pemeliharaan maka antara pengusul dan mitra telah disepakati beberapa permasalahan yang amat prioritas untuk diselesaikan sesegera mungkin. Beberapa hal yang dipandang amat krusial diselesaikan untuk pengembangan usaha kelompok kedepan yaitu:

1. Pendapatan peternak yang sangat rendah. Pendapatan peternak yang rendah dapat disebabkan peternak tidak memaksimalkan penerimaan dari usaha peternakan mereka. Salah satu sumber penerimaan bagi peternak adalah pemanfaatan kotoran sapi. Kotoran sapi bagi masing-masing peternak tidak dikelola dengan baik. Kotoran sapi dibiarkan menumpuk dikandang dan disamping kandang dan dibiarkan menggunung. Hal ini juga akan menyebabkan lingkungan yang kurang bersih terutama di musim hujan yang akan mengancam pada kesehatan sapi maupun peternaknya. Lingkungan disekitar kandang pun akan menghasilkan bau yang kurang sedap.

2. Kelompok ternak ini masih sama-sama mempunyai masalah dalam bidang manajemen teknis beternak sapi seperti bidang produksi, pengetahuan pakan dan pemeliharaan sapi yang masih kurang baik serta penanggulan dan pencegahan penyakit. Peternak hanya melepaskan sapi mereka di padang rumput yang luas sehingga kecukupan pakan sapi tidak terkontrol. Peternak jarang memberikan kosentrat kepada sapi dan begitu juga, peternak kurang memperhatikan perkandangan dan terutama kebersihan kandang.

\section{METODE}

\section{Tempat Pelaksanaan Program}

Kegiatan ini dilakukan pada kelompok tani ternak Sungkai Permai yang berlokasi berdekatan dengan kampus Universitas Andalas yaitu di kampung Bukit Sungkai Kelurahan Lambuang Bukit Kecamatan Pauh Kota Padang, Sumatera Barat.

\section{Metode Pendekatan}

Metode pendekatan yang ditawarkan untuk pelaksanaan solusi adalah:

a. Metode pendekatan yang digunakan untuk merintis usaha pupuk organik adalah metode penyuluhan dan metode demontrasi pembuatan pupuk organik serta metode pendampingan dalam proses produksi, packing dan pemasaran. Pengusul akan memberikan pengetahuan dan motivasi melalui penyuluhan tentang prospek dan keuntungan usaha pupuk organik, proses produksi, packing dan pemasaran. Kemudian pengusul akan melakukan demontrasi pembuatan pupuk organik. Selanjutnya pengusul akan mendampingi mitra dalam proses packing dan pemasaran.

b. Metode pendekatan yang digunakan untuk peningkatan manajemen teknis beternak sapi potong dengan metode penyuluhan dan demontrasi tentang tentang pengetahuan bibit yang unggul, pengetahuan pakan (baik jenis dan jumlah pakan) dan pengetahuan tentang kandang dan pemeliharaan serta penanganan dan pencegahan penyakit. 
c. Metode pendekatan untuk memotivasi peternak untuk memelihara sapi secara intensif yaitu dengan cara penyuluhan tentang manfaat dan kelebihan beternak sapi potong secara intensif.

\section{Prosedur Kerja}

\section{Merintis usaha pupuk organik.}

Prosedur kerja yang dilakukan pengusul bersama mitra dalam merintis usaha pupuk organik adalah:

- Mitra menyediakan alat-alat pembuatan pupuk organik seperti: sekop, cangkul, sepatu boot, ayakan/saringan, plastik, timbangan dan sarung tangan. Mitra juga menyediakan bahan-bahan seperti kotoran ternak (2 ton/2000 kg), biang (inokulan jamur Trichoderma) dari nasi yang difermentasi dalam bambu, bahan organik (sisa pakan/rumput alang-alang atau jerami serta titonia/gamal ) secukupnya, dan sabut kelapa

- Pengusul mendemontrasikan pembuatan pupuk dibantu oleh mitra dengan prosedur: a) campur semua bahan; b) semua bahan yang telah dicampu di tumpuk pada suatu tempat; c) Diperam selama 3 minggu dan sekali seminggu di balik-balik; d) setelah matang lalu pupuk dikering anginkan; d) giling dan atau ayak pupuk organik; e) packing dalam karung plastik; dan f) dipasarkan.

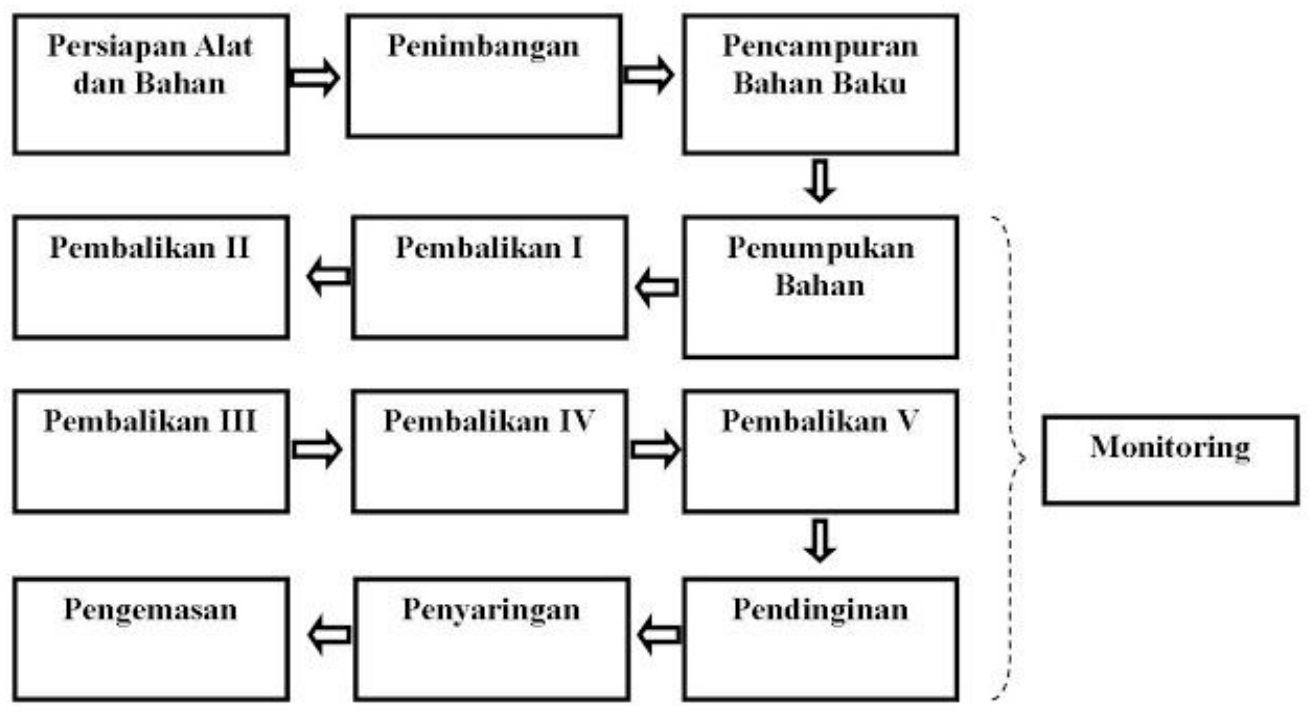

Gambar 2. Prosedur Kerja Pembuatan Pupuk Organik

\section{Peningkatan Manajemen Teknis Beternak Sapi Potong}

Prosedurnya yang dilakukan saat penyuluhan peningkatan manajemen teknis beternak sapi potong adalah:

- Anggota kelompok hadir pada tempat dan waktu yang telah ditentukan

- Acara penyuluhan akan dipandu oleh seorang MC

- Penyampaian materi akan dilakukan tiga sesi dan masing-masing topik akan disampaikan oleh tim pengusul sesuai keahlian

- Anggota kelompok diberikan kesempatan bertanya

- Penutup. 


\section{Memotivasi Peternak Untuk Memelihara Sapi Secara Intensif}

- Prosedur kerja penyuluhan tentang motivasi akan dilakukan seperti point di atas

- Prosedur kerja membuat satu percontohan pemeliharaan sapi secara intensif: o Mitra menyediakan satu peternak yang akan dijadikan percontohan beternak secara intensif

- Pengusul mendampingi mitra membuat satu percontohan usaha peternakan sapi potong secara intensif dengan menyediakan padang rumput unggul sesuai jumlah ternak.

\section{HASIL DAN PEMBAHASAN}

\section{Merintis Usaha Pupuk Organik}

Pelaksanaan dari kegiatan ini diawali dengan konfirmasi program dengan ketua kelompok dan sebahagian anggota untuk menetapkan waktu dan lokasi serta program yang akan dijalankan. Pelaksanaan dilakukan disebuah kandang milik anggota karena program ini disamping memberikan penyuluhan juga mendemontrasikan cara membuat pupuk organik. Pada saat pelaksanaan semua anggota kelompok berkumpul dan telah menyiapkan tempat pembuatan pupuk, alat dan bahan untuk pembuatan pupuk organik seperti kotoran sapi yang sudah diangin-anginkan (kering air), hijauan, bahan trichoderma, sekop, cangkul, ayakan dan peralatan lainnya untuk pembuatan pupuk organik. Tahap awal kegiatan adalah penyuluhan pembuatan pupuk organik. Anggota kelompok berkumpul disebuah ruangan yang telah disiapkan.

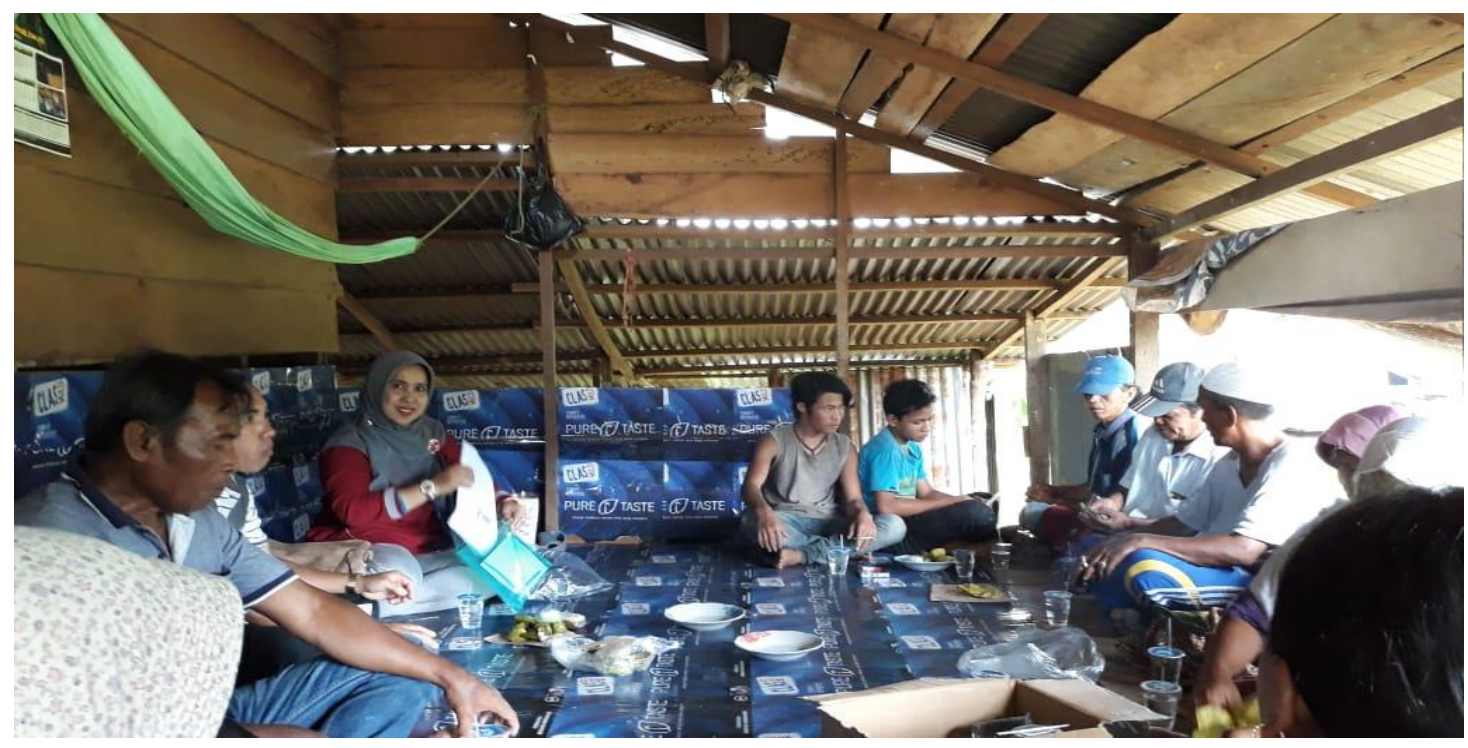

Gambar 3. Penyuluhan Pembuatan Pupuk Organik

Pada kegitan ini dijelaskan tentang kelebihan dan manfaat menggunakan pupuk organik untuk tanaman serta tujuan membuat usaha pupuk organik. Masyarakat semakin bertambah pengetahuannya tentang pemanfaatan pupuk organik bagi tananam. Biasanya 
masyarakat menggunakan pupuk kandang secara langsung ke tanaman tanpa dikomposkan terlebih dahulu. Hal ini menyebabkan unsur hara yang dibutuhkan lebih sedikit dibandingkan dengan pupuk organik yang dikomposkan dan penyediaan unsur haranya bagi tanaman lebih lama.

Namun pupuk organik yang telah dikomposkan dapat menyediakan hara dalam waktu yang lebih cepat dibandingkan dalam bentuk segar, karena selama proses pengomposan telah terjadi proses dekomposisi yang dilakukan oleh beberapa macam mikroba, baik dalam kondisi aerob maupun anaerob. Disamping itu, penggunaan pupuk organik pada tananam dengan tujuan memperbaiki dan menambah unsur hara tanah yang sudah semakin kering akibat penggunaan pupuk kimia.

Pada penyuluhan ini juga dijelaskan kepada anggota kelompok tentang jumlah kerugian yang mereka dapati ketika mereka tidak mengolah kotoran sapi mereka dan membuangkan secara percuma. Kami menjelaskan bahwa berat daging yang dihasilkan dari seekor sapi lebih kurang 35\% dari berat badan. Misalkan berat badan seekor sapi $295 \mathrm{~kg}$ maka berat daging yang dihasilkan sebanyak 295 X 35\% = $104 \mathrm{~kg}$. Dan sisanya adalah tulang dan isi perut yang akan menjadi kotoran. Betapa banyaknya yang kita buang dari seekor sapi padahal peternak sudah susah payah setiap hari dan mengorbankan materi dan tenaga untuk mencari dan memberi makan sapi mereka. Jika kotoran sapi tidak dimanfaatkan secara maksimal berarti kita hanya mendapatkan 35\% dari semestinya $100 \%$ yang kita dapatkan.

Oleh itu, kami menjelaskan bahwa disamping peternak dapat menggunakan pupuk organik untuk tanaman pertanian mereka seperti tanaman padi, buah-buahan dan sayursayuran namun peternak dapat menjual pupuk organik yang mereka olah. Pada kegiatan penyuluhan ini mereka baru sadar bahwa jika pupuk organik ini diolah maka dapat jual dan menambah penghasilan mereka. Selama ini mereka hanya menyadari manfaat pupuk organik untuk tananam mereka sendiri atau digunakan sendiri. Kami menjelaskan analisa usaha pupuk organik. Harga modal untuk $1 \mathrm{~kg}$ pupuk organik lebih kurang Rp 1.000 dan akan mengahasilkan keuntugan Rp 1.000 - Rp 1.500 per kg. Akhirnya anggota kelompok semakin semangat dan termotivasi untuk mengolah pupuk organik mereka.

Tahap selanjutnya adalah kegiatan demonstrasi pembuatan pupuk organik oleh abdimas kepada anggota kelompok. Pertama sekali anggota kelompok diajarkan cara membuat mikroba inokulan (Trichoderma). Cara pembuatannya adalah siapkan satu ruas bambu yang telah kering air dimana lebih kurang satu minggu setelah ditebang. Masak nasi setengah matang dan dinginkan lalu masukkan nasi ke dalam tabung bambu dan ditutup dengan kertas koran atau kertas tisu. Lalu diperam selama empat hari pada suhu kamar. Setelah itu biakan tricho dapat digunakan untuk pupuk organik. 
Website. http://hilirisasi.lppm.unand.ac.id e-ISSN: 2621-7198

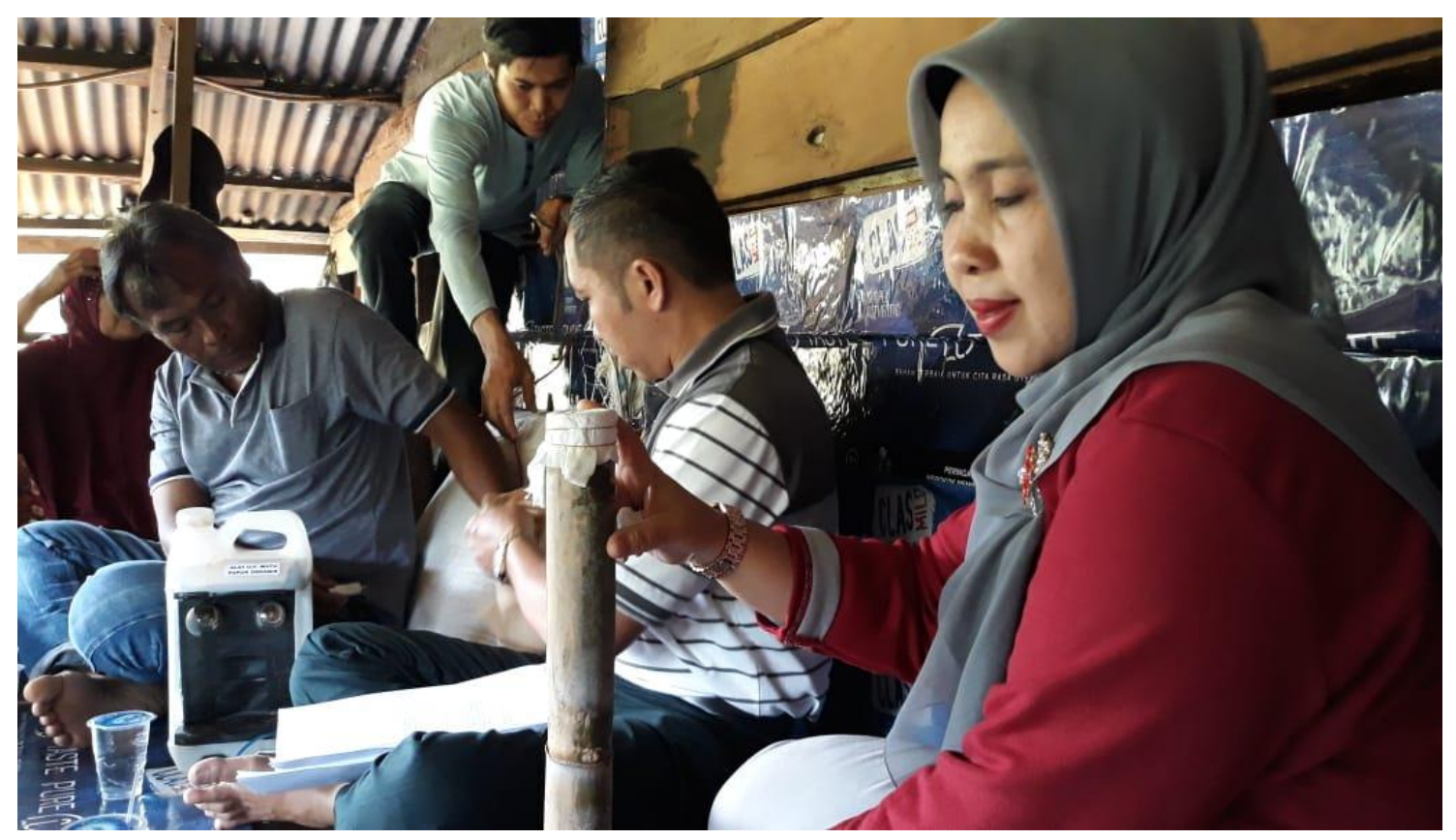

Gambar 4. Demonstrasi Pembuatan Pupuk Organik

Langkah selanjutnya, anggota kelompok telah menyiapkan kotoran sapi yang telah kering air dengan kadar air 60\% dengan cara menumpuk kotoran pada suatu tempat yang tidak terkena hujan. Kotoran sapi yang sudah kering air siap untuk diolah seperti terlihat pada gambar di bawah ini.

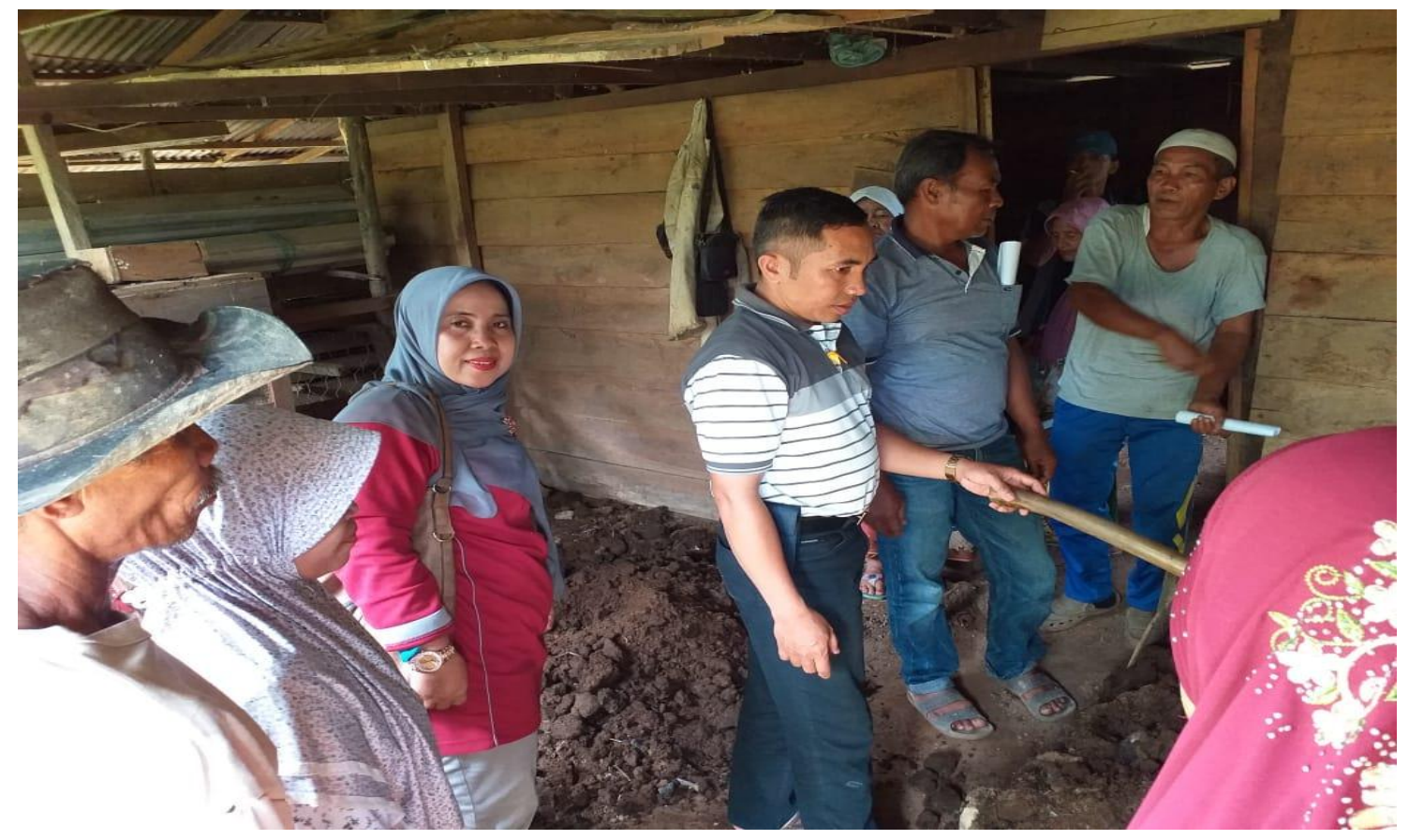

Gambar 5. Kotoran Sapi Yang Sudah Siap Untuk Diolah 
Tumpukan kotoran sapi diatas lantai bambu agar airnya keluar lalu tambahkan sisa tanaman atau rumput dan legum lapangan bahkan jerami dan rumput kering dapat digunakan sebagai bahan kompos. Perbandingan kotoran sapi dan sisa tanaman yang digunakan adalah $2: 1$ yaitu dua bagian kotoran sapi dan satu bagian sisa tanaman. Lalu tambahkan inokulan dan biarkan terfermentasi selama dua minggu.

Lakukan pengecekan suhu fermentasi dengan meraba bagian dalam dan terasa panas (suhu 45derajat Cilcius). Jika telah difermentasi selama satu minggu namun tidak terasa panas berarti proses fermentasinya tidak berjalan. Dan jika permukaan dalam tumpukan terlihat spora jamur yang putih kebiruan menandakan proses fermentasi berjalan sempurna. Pada pagi hari coba dibuka tumpukan dan nampak berasap menandakan fermentasi sempurna. Jerami, rumput akan hancur dan pupuk sudah relatif kering. Pupuk pun juga dibalik-balik setiap minggu dan setelah dua minggu, gumpalangumpalan pupuk dipecahkan dan sudah bisa digunakan. Jika pupuk akan dijual maka pupuk kompos harus digiling. Sebelum digiling, pupuk harus dikeringkan terlebih dahulu dengan kering angin atau dijemur. Jika pupuk dikepal tidak terbentuk bongkahan berarti sudah kering dan sudah bisa digiling.

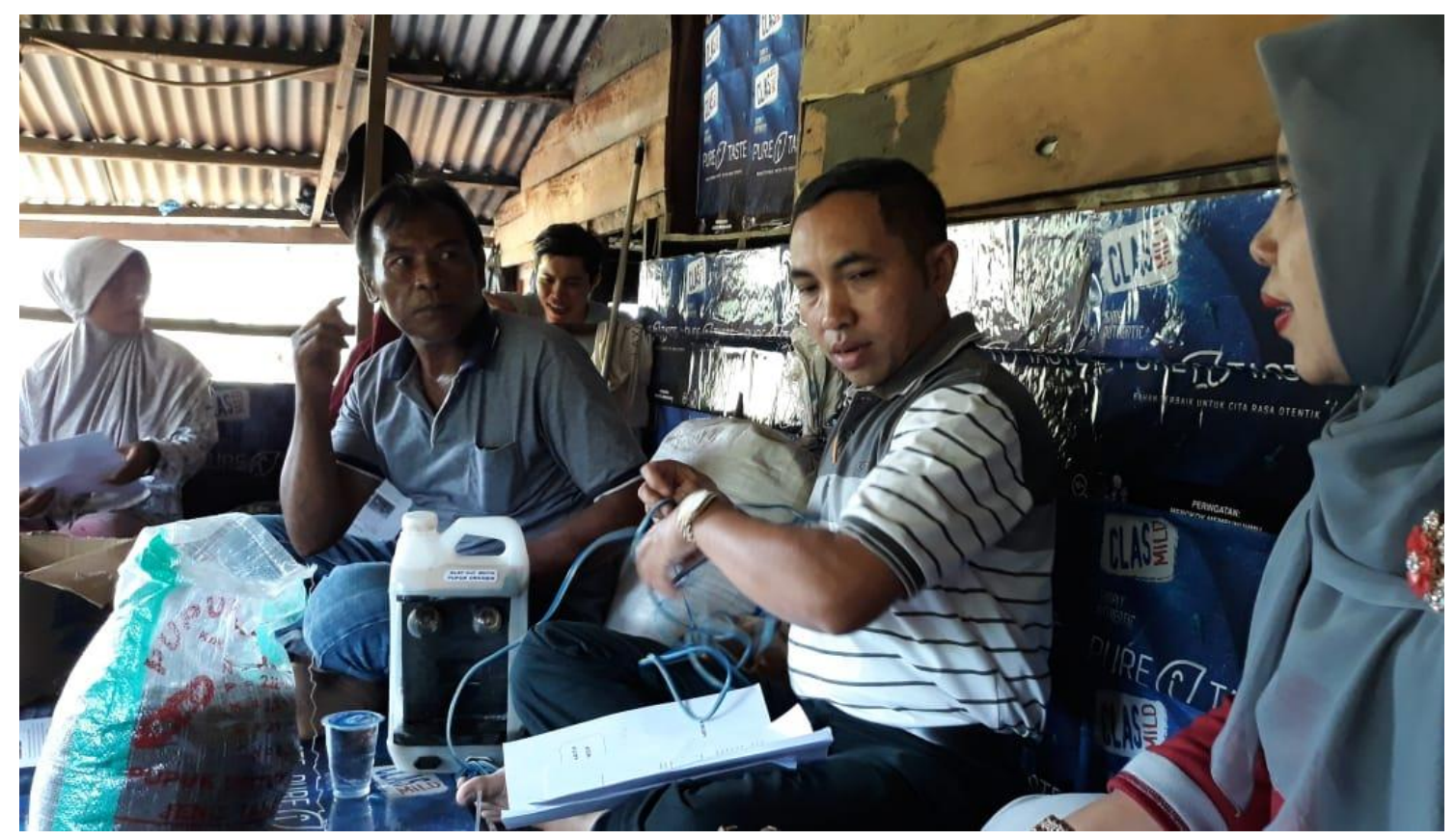

Gambar 6. Proses Packing atau Pengemasan Pupuk Organik

Selanjutnya proses packing atau pengemasan dari pupuk organik untuk dijual. Kelemahan dari pupuk organik olahan peternak rakyat adalah tidak adanya proses pengemasan yang baik. Suatu produk akan laku terjual salah satunya ditentukan oleh merek dan pengemasan. Oleh itu kami membuatkan design merek yang akan ditempelkan diplastik kemasan pupuk organik ini. Merek ini akan disablon pada plastik kemasan yang berwarna putih. Tujuan dari merek ini adalah memberikan identitas pada suatu produk supaya lebih mudah dikenali oleh konsumen. 


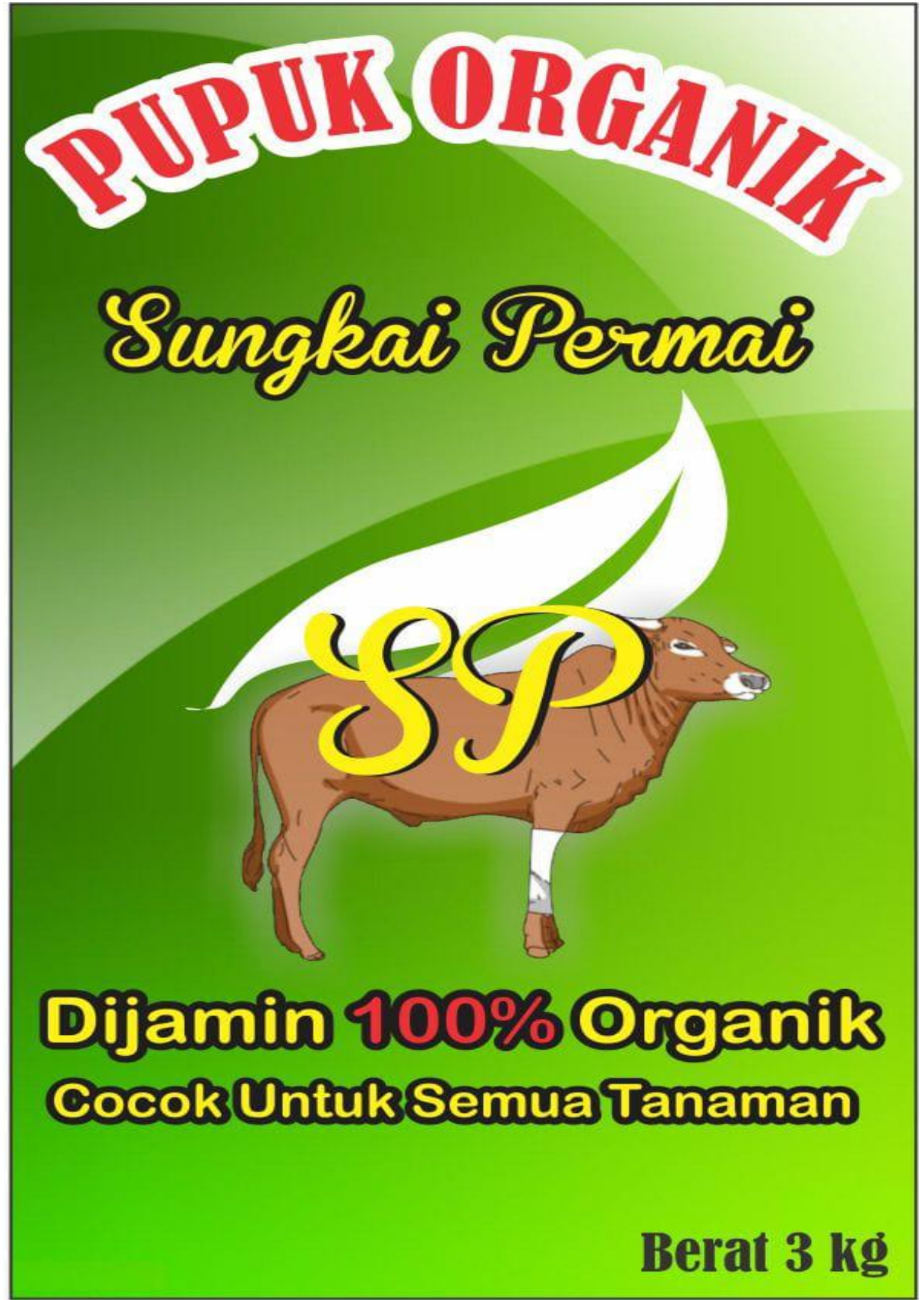

Gambar 7. Merek Pupuk Organik

Pupuk organik yang telah diberi merek dan di packing dalam kantong dengan berat $3 \mathrm{~kg}$. Harga perkantongnya dijual ke toko pupuk atau kios bunga adalah Rp 5.000 sampai Rp 6.000. Semoga usaha pupuk organik kelompok ternak Sungkai Permai dapat berkelanjutan dan dapat meningkatkan pendapatan peternak sehingga peternak dapat tersenyum. 


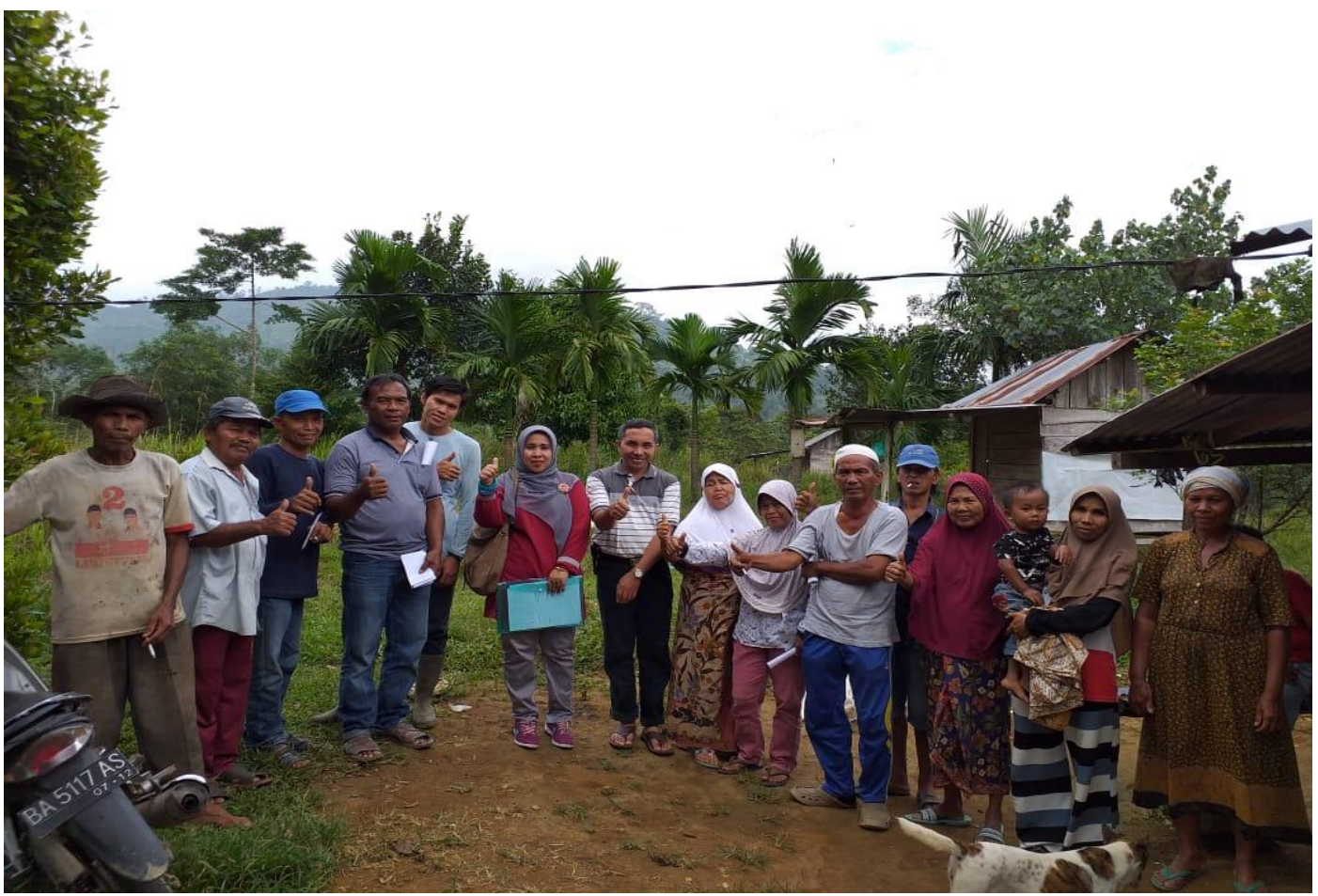

Gambar 8. Visitasi ke Kelompok Tani Sungkai Permai

\section{KESIMPULAN DAN SARAN}

\section{Kesimpulan}

Dari kegiatan ini dapat disimpulkan bahwa: 1. anggota kelompok ternak Sungkai Permai telah dapat mengadopsi pengetahuan dan keterampilan pembuatan pupuk organik dan dapat mentranfer teknologi tersebut kepada anggota kelompok yang tidak dapat hadir. 2. anggota kelompok ternak Sungkai Permai telah dapat mengolah atau memproduksi pupuk organik skala sederhana dan 3. usaha pupuk organik kelompok ternak Sungkai Permai telah mempunyai merek usahanya sendiri dan mencoba untuk mengkomersilkannya.

\section{Saran}

Dalam rangka untuk peningkatan dan melanjutkan program yang ada, diperlukan saran-saran sebagai berikut : 1 . perlu pendampingan yang intensif berkelanjutan kepada mitra untuk bisa meningkatkan produksinya, 2. Kelompok ternak Sungkai Permai ini perlu diberi bantuan sarana dan prasarana pembuatan UPPO seperti mesin giling dan mesin potong, bak fermentasi, gerobak motor, 3. perlu dikembangkan usaha terintegrasi yaitu usaha sapi potong, pengolahan pupuk organi dan penanaman tanaman buah seperti jeruk, alpukat, pepaya dan tanaman lainnya, dan 4. dianjurkan agar kelompok ternak ini dapat membangun kelembagaan koperasi untuk pemasaran produknya. 


\section{UCAPAN TERIMA KASIH}

Kami tim dan kelompok ternak Sungkai Permai mengucapkan terima kasih kepada Lembaga Penelitian dan Pengabdian kepada Masyarakat (LPPM) Universitas Andalas yang telah mempercayakan kami untuk melaksanakan kegiatan ini. Atas sokongan materil dan moril kami telah dapat memberikan kontribusi ilmu kepada masyarakat di salingka kampus.

\section{DAFTAR PUSTAKA}

Badan Pusat Statistik. 2015. Pauh Dalam Angka, Padang

Ramaiyulis. 2017. Pengolahan Pupuk Organik Sesuai Standar Mutu. Politeknik Pertanian Negeri Payakumbuh, Payakumbuh.

Triatmojo, S. 2013. Bahan Ajar Teknologi Penanganan Limbah Peternakan Dasar. Jurusan Teknologi Hasil Ternak Fakultas Peternakan Universitas Gadjah Mada, Yogyakarta. (Tidak Dipublikasikan). 